\title{
Selecting Television Programs for Language Learning: Investigating Television Programs from the Same Genre
}

\author{
STUART WEBB* \\ Victoria University of Wellington
}

Received: 30 January 2010 / Accepted: 23 March 2010

\begin{abstract}
The scripts of 288 television episodes were analysed to determine the extent to which vocabulary reoccurs in television programs from the same subgenres and unrelated television programs from different genres. Episodes from two programs from each of the following three subgenres of the American drama genre: medical, spy/action, and criminal forensic investigation were compared with different sets of random episodes. The results showed that although there were an equivalent number of running words in each set of episodes, the episodes from programs within the same subgenre contained fewer word families than random programs. The findings also showed that low frequency word families (4000-14,000 levels) reoccur more often in programs within the same subgenre. Together the results indicate that watching programs within the same subgenre may be an effective approach to language learning with television because it reduces the lexical demands of viewing and increases the potential for vocabulary learning.
\end{abstract}

\section{KEYWORDS:}

Comprehension, corpus linguistics, genre, incidental vocabulary learning, television, vocabulary coverage, word frequency.

\section{RESUMEN}

Los guiones de 288 episodios televisivos se analizaron para determinar el alcance de la recursividad del vocabulario en programas de televisión del mismo subgénero y en programas no relacionados de géneros diferentes. Se compararon episodios de tres subgéneros del drama americano: médico, de espías/acción y de investigación forense, con varios grupos de episodios elegidos al azar. Los resultados muestran que, aunque el número de palabras en cada grupo de episodios era equivalente, los episodios del mismo subgénero contienen menos familias de palabras que aquellos elegidos al azar. Los hallazgos mostraron que las familias de baja frecuencia (niveles de 4.000-14.000) se repiten con más frecuencia en los programas del mismo subgénero. En conjunto, los resultados indican que el visionado de programas del mismo subgénero puede ser un método efectivo para aprender el lenguaje por medio de la televisión porque reduce la demanda léxica de la proyección y aumenta el potencial de aprendizaje de vocabulario.

\section{PALABRAS CLAVE:}

Comprensión, Lingüística de corpus, género, aprendizaje incidental, televisión, cobertura del vocabulario, frecuencia léxica.

\footnotetext{
*Address for correspondence: Stuart Webb. School of Linguistics and Applied Language Studies, Victoria University of Wellington, PO Box 600, Wellington, New Zealand. Tel: 644463 9779; Fax: 644463 5604; Email: stuart.webb@vuw.ac.nz
} 


\section{INTRODUCTION}

Television is a valuable resource for language learning. English language television programs are widely available in English as a second language (ESL) and English as a foreign language (EFL) contexts, and research indicates that foreign language learners are motivated to learn through watching television (Bada \& Okan, 2000; Gieve \& Clark, 2005). Research has also shown that L2 learners may incidentally learn vocabulary through watching television and short videos (d'Ydewalle \& Pavakanun, 1995; d'Ydewalle \& Van de Poel, 1999; Koolstra \& Beentjes, 1999; Neuman \& Koskinen, 1992; Pavakanun \& d'Ydewalle, 1992), and that L2 viewers may learn as many words incidentally through watching television as they would through reading a script of the program (Neuman \& Koskinen, 1992). Television provides authentic L2 aural input which contributes to learning the spoken form of words and is thus a useful complement to learning through reading.

In a corpus-driven study looking at the number of words needed to understand the vocabulary in television programs, Webb and Rodgers (2009a) found that a vocabulary size of 3000 word families plus proper nouns and marginal words provided $95.45 \%$ coverage of a corpus made up of 88 television programs from a variety of genres. They reported that knowing the most frequent 3000 word families may be sufficient for adequate comprehension of television programs and that a learning approach which involved regular viewing could lead to large incidental vocabulary learning gains. They suggested that for learners with the appropriate vocabulary size, increased viewing should lead to increased vocabulary learning because research on incidental vocabulary learning has shown that the more unknown words are encountered in context, the more likely they are to be learned (Horst, Cobb, \& Meara, 1998; Jenkins, Stein, \& Wysocki, 1984; Rott, 1999; Saragi, Nation, \& Meister, 1978; Waring \& Takaki, 2003; Webb, 2007).

Webb and Rodgers (2009a) findings also shed light on differences between television genres. Children's programs were found to have the smallest vocabulary load; the most frequent 2000 word families, plus proper nouns and marginal words accounted for 95\% coverage. The most frequent 3000 word families plus proper nouns and marginal words accounted for $95 \%$ of American drama, older programs, situation comedies and British programs. The genres with the greatest proportions of low frequency words were news stories and science fiction programs. Results also indicated that coverage is likely to vary between episodes of programs leading Webb and Rodgers to suggest that randomly viewing programs may limit comprehension. Instead they proposed watching programs from within the same subgenre that have similar topics and storyline.

The aim of the present study is to examine the number of word types and word families in television programs from the same subgenre and unrelated television programs from different genres, as well as the number of encounters with low frequency words. Determining the number of word types and families provides some indication of the lexical demands of 
text. This is useful because viewers are unlikely to watch L2 television programs that they cannot understand. Examining the number of encounters with low frequency words indicates the potential for vocabulary learning through reading or hearing a text. Comparing the number of encounters with low frequency words in different types of programs is also important because it may indicate how to effectively use television for language learning and provide direction towards optimizing vocabulary learning.

\section{BACKGROUND}

In corpus-driven research, few assumptions are made in advance of the analysis. Instead the patterns revealed in the corpus analysis provide the basis for subsequent descriptions of the corpus (Biber, 2009). Corpus-driven studies focused on vocabulary are well established and have looked at the vocabulary load and potential for incidental vocabulary learning in related and unrelated text (Hwang \& Nation, 1989; Schmitt \& Carter, 2000; Sutarsyah, Nation, \& Kennedy, 1994), and the number of words necessary for comprehension of spoken discourse (Adolphs \& Schmitt, 2003; Meara, 1991, 1993; Nation, 2006), written discourse (Meara, 1993; Nation, 2006), television programs (Webb \& Rodgers, 2009a), and movies (Webb \& Rodgers, 2009b). Corpus-driven research has also focused on the potential for incidental vocabulary learning through encountering language in speech and writing (Cobb, 2007; Horst, 2009; Meara, Lightbrown, \& Halter, 1997, Webb, 2010a; Webb \& Rodgers, 2009a; Wodinsky \& Nation, 1988).

Corpus-driven studies on narrow reading (reading texts with related content) have shown that when there are a similar number of running words in related and unrelated texts; related texts are likely to have a smaller lexical load than unrelated texts because there are fewer different words in related texts (Hwang \& Nation, 1989; Schmitt \& Carter, 2000; Sutarsyah, Nation, \& Kennedy, 1994). Sutarsyah, Nation, and Kennedy (1994) examined the vocabulary in a single Economics text in comparison to a collection of academic texts with a similar number of running words. Their analysis showed that the vocabulary load of a single text is likely to be smaller than unrelated texts. The Economics text was made up of a much smaller number of types $(9,469)$ and word families $(5,438)$ than the academic texts $(12,744$ and 21,399, respectively).

Hwang and Nation (1989) examined the vocabulary in running stories (newspaper stories and their subsequent follow-up stories) and unrelated stories from newspapers. An analysis of 20 sets of four running stories and 20 sets of four unrelated stories showed that lower frequency word families (words outside of the 2000 most frequent word families) were encountered more often in the related texts than in the unrelated texts. This indicates that there is greater potential for vocabulary learning through reading related texts because research has consistently shown that as the number of encounters with unknown words in context increases, the words are more likely to be learned (Horst, Cobb, \& Meara, 1998; Jenkins, 
Stein, \& Wysocki, 1984; Rott, 1999; Saragi, Nation, \& Meister, 1978; Waring \& Takaki, 2003; Webb, 2007). Hwang and Nation suggested that narrow reading provided better conditions for learning low frequency words and reduced the vocabulary load by decreasing the number of times that $\mathrm{L} 2$ readers would need to look up words in dictionaries.

A similar study by Schmitt and Carter (2000) looked at the vocabulary in a series of nine newspaper stories focused on the death of Princess Diana and the vocabulary in nine unrelated newspaper stories. Both sets of stories consisted of the same number of running words $(7,843)$. The analysis showed that there were 156 fewer types and a greater number of encounters with those words in the related stories than in the unrelated stories. Schmitt and Carter concluded that reading related stories lowers the lexical load for L2 learners and may allow for earlier learning with authentic reading materials.

The studies investigating narrow reading indicate that related texts are likely to have fewer word types and word families than unrelated texts, and a great number of encounters with the low frequency words in the texts. The studies of narrow reading have been useful because they provide direction on materials selection. Reading texts with similar topics may be effective because it lowers the lexical load and provides better conditions for vocabulary learning.

In the only study that has compared related and unrelated television programs, Rodgers and Webb (in press) compared the vocabulary in episodes of the same television programs and in unrelated television programs. Approximately 24 episodes from each of six television programs from a single genre (American drama) were compared with sets of unrelated episodes from programs from a variety of genres. Both sets of episodes (related and unrelated) had the same number of running words. The results showed that there were fewer word families in each of the sets of episodes from a single program than in the sets of unrelated programs. Rodgers and Webb also found that low frequency word families (words from the 4,000-14,000 BNC word lists) were encountered more often in each of the sets of episodes from the same program than the sets of unrelated episodes. The findings indicate that it may be more effective to watch different episodes of the same television program rather than episodes of different programs because the vocabulary load is likely to be lower when watching episodes of the same program. Although there are many factors that contribute to comprehension of a text, vocabulary has the largest effect (Laufer, 1989); if you do not know the words that occur in a text it is difficult to understand it.

The present study expands on Rodgers and Webb's (in press) research by investigating different television programs from the same subgenre rather than different episodes of the same program. The scripts of 142 episodes from six television programs from three subgenres of television drama - medical dramas, spy/action dramas, and criminal forensic investigation dramas were compared to three sets of random television programs (146 episodes). Each of the three subgenres was made up of a full season from two television programs (approximately 48 episodes in each). Each of the subgenres and the sets of random programs 
had the same number of running words. The aim of the study is to determine whether related programs have a lower lexical load and a greater number of encounters with low frequency words than unrelated programs. The analysis may indicate an effective approach to using television for language learning by providing direction on how to reduce the lexical burden and optimize vocabulary learning.

\section{THE PRESENT STUDY}

\subsection{Research questions}

The present study seeks to address the following research questions:

1. Are there fewer word types and families in television programs from the same subgenre than in unrelated programs?

2. Does vocabulary reoccur more often in different episodes of programs from the same television subgenre than in random television programs?

3. How many word families are encountered 10 or more times in a full season of two television programs (approximately 48 episodes) within the same subgenre or an equivalent amount of random television episodes?

\subsection{Materials}

The scripts of 288 television episodes were analyzed in this study. The episodes had a total running time of 203 hours and 49 minutes and a mean running time of 42 minutes. The running time for all but seven of the programs was one hour including commercials; however, commercials were not included in the analysis. To compare the vocabulary within programs from the same subgenre and unrelated programs, 142 episodes from six different television programs: 24, Alias, Crossing Jordan, CSI, Grey's Anatomy, and House, and 146 episodes from random programs were analysed in the study. The episodes for each of the programs made up one complete season. A season of a television series consists of a number of episodes broadcast in the same programming year, where an episode is a single instance of a series. The aim of the selection process for the six programs was to choose three pairs of programs that contained similarity in content within each pair, but differences between each pair. Comparing three pairs of related programs to sets of unrelated television programs may provide a valid representation of related and unrelated content in the American television drama genre.

The set of 142 episodes were selected according to the following criteria: genre, subgenre, availability, running time, date when first aired, and place of origin. All six programs were classified as American dramas with the three pairs of programs belonging to 
specific subgenres of American drama. The programs and their subgenres are shown in Table 1.

\begin{tabular}{ll}
\hline Subgenre & Program \\
\hline Medical dramas & House \\
& Grey's Anatomy \\
Criminal forensic investigation dramas & CSI \\
& Crossing Jordan \\
Spy/action dramas & 24 \\
& Alias \\
\hline
\end{tabular}

Table 1. Subgenres and programs.

House and Grey's Anatomy were medical dramas, CSI and Crossing Jordan were criminal forensic investigation dramas, and Alias and 24 were spy/action dramas. These episodes had an average running time of 43 minutes and were first aired between 2001 and 2006. The scripts were downloaded from the Internet. It is important to note that Internetavailable television scripts do not always replicate dialogue with $100 \%$ accuracy. However, the scripts should provide a reliable assessment of the vocabulary in television programs.

The 146 randomly selected television episodes were used for comparison with the episodes in the six programs. These episodes were all classified as American, originally aired between 1963 and 2009, and had running times of approximately 22 minutes (broadcast as a 30 minute program including commercials) or 44 minutes (broadcast as a 60 minute program). Three sets of different episodes were created for comparison with the three subgenres. Programs from a wide range of genres were used in each set of comparison programs, and no set contained multiple episodes of the same program. It is important to note that this does not make certain that all of the programs had completely unrelated content as two shows from the same genre may have been included. However, the degree of overlap in content was likely to be considerably less than in the episodes within each subgenre. The appendix lists all of the programs from one of the three random sets.

The sets of random episodes were made up of the same number of running words as each subgenre. To ensure that the random sets had the same number of running words as each of the three subgenres, one episode in each of the sets did not include all of its running words. The random sets were created with an aim of including as many running words as possible from the final episode in the set. Comparing corpora with an equal number of running words is necessary for a valid comparison (Nation \& Webb, 2011).

Words which were not spoken in the scripts such as stage directions, setting features, and speakers' names were removed. Only the spoken words from the programs were 
analysed. Contractions, connected speech, and hyphenated words were changed to conform with the spellings used in Nation's (2004) British National Corpus (BNC) word lists. Contractions accounted for $0.39 \%$ of the tokens in the study $(0.28 \%$ of the tokens in the six programs and $0.49 \%$ of the tokens from the random episodes). For example, s'pose, ol', wanna, and kinda were changed to suppose, old, want to, and kind of, respectively. If the spellings were not changed these items would have been classified as being less frequent than the most frequent 14,000 word families. However, it should be noted that knowing the changed spellings does not mean that the original forms would also be known. For example, learners may know old and want to but they might not recognize ol' and wanna. Webb \& Rodgers (2009a, 2009b) suggest that a high percentage of contractions may hinder the vocabulary comprehension and learning in speech. To the best of our knowledge no study has yet investigated the effect that the percentage of contractions and connected speech may have on comprehension and incidental learning. The relatively small percentage of items that were changed to conform to the spellings in the BNC lists would suggest that the percentage of contractions in the episodes, at least as indicated by the scripts, would be quite small.

\subsection{Software and word lists}

The RANGE software (Nation \& Heatley, 2002) was used to analyze the scripts. RANGE is a computer program which lists the words that occur in a text according to their frequency. Nation's (2004) 14 lists $^{1}$ of 1,000 word families were used with the RANGE software to show the 1,000 word level $(1,000-14,000)$ at which the words in the programs occurred. The lists were based on the frequency and range of occurrence of words in the BNC. The word families in the lists were categorized as Level 6 according to Bauer and Nation's (1993) classification of word families. Level 6 word families include inflections and more than 80 derivational affixes. All word stems were free forms not bound forms. ${ }^{1}$ Less frequent words than the most frequent 14,000 word families were classified by the RANGE program as proper nouns, marginal words (i.e. oh, uh, mmm, ah) and Not in the Lists. The proper nouns list has over 13,000 entries, but this will rarely account for all of the proper nouns in an analysis of a corpus, and a number of proper nouns will be classified by RANGE as Not in the Lists (words less frequent than the most frequent 14,000 word families). Proper nouns found in the Not in the Lists were reclassified as proper nouns and added to the proper nouns totals. It should also be noted that several words such as: bartender, cheerleader, donut, and email, which were classified as Not in the Lists are likely to be known by learners with a vocabulary size of 3,000 word families. This suggests that the coverage figures may be slightly conservative. 
The RANGE program and the words lists are freely available at Paul Nation's website: http://www.victoria.ac.nz/lals/staff/paul-nation/nation.aspx.

If the most frequent 3,000 word families plus proper nouns and marginal words is sufficient for comprehension of television programs (Webb \& Rodgers, 2009a), examining the low frequency vocabulary found in the 4,000-14,000 word lists which may be unknown to L2 learners may indicate the potential for incidental vocabulary learning. The number of times word families from these word lists were encountered may indicate whether unknown vocabulary is more likely to reoccur in related television programs than unrelated programs. Research on incidental vocabulary learning from reading indicates that from six (Rott, 1999) to 20 encounters (Waring \& Takaki, 2003) may be needed to learn words with the amount of knowledge gained dependent on the contexts in which the words are encountered (Webb, 2008). In corpus-driven studies, Nation and Wang (1999) used 10 or more encounters with unknown words as the number of encounters necessary for incidental vocabulary learning through reading, Cobb (2007) used six encounters, and Horst (2009) used 10 or more encounters for learning through listening. Because the number of encounters necessary for learning can vary from word to word (Webb, 2008), it is useful to look at different numbers of encounters with words. One or two encounters is likely to lead to gains in knowledge of form but minimal gains in knowledge of meaning, five to nine encounters may lead to partial knowledge of a number of aspects of knowledge, and 10 or more encounters with words may indicate a good chance of learning the meanings of words and other aspects of knowledge.

\section{RESULTS}

The cumulative coverage of the three subgenres, the random episodes with which they were matched, and the number of tokens, types, and families in each, is shown in Table 2. The last three rows of the table show the number of tokens, types and word families in each set of episodes. The episodes consisted of 1,330,268 tokens; 665,134 tokens were from the three subgenres $(266,856,182,620,215,658)$ and 665,134 were from the random episodes $(266,856,182,620,215,658)$. The number of word types found in the subgenres and the random episodes was inconsistent. The medical subgenre $(11,688)$ and the spy/action subgenre $(7,570)$ contained fewer word types than the matching random episodes $(12,626$ and 10,233 , respectively). However, the criminal forensic investigation subgenre $(11,548)$ consisted of more word types than the matching random episodes $(11,136)$. The results for word families were more consistent. The final row of Table 2 shows that there were $16 \%$ fewer word families in the medical subgenre $(5,930)$ than in the matching set of random episodes $(7,069), 25 \%$ fewer word families in the spy/action subgenre $(4,450)$ than the matching set of random episodes (5,964), and $1 \%$ fewer word families in the criminal forensic investigation subgenre $(6,356)$ than the matching set of random episodes $(6,417)$. The 
relatively large number of types and families in the criminal forensic investigation subgenre in comparison to the other two subgenres indicates that there may have been less overlap in content between the two programs in the criminal forensic investigation subgenre.

\begin{tabular}{|c|c|c|c|c|c|c|}
\hline Word list & $\begin{array}{l}\text { Medical } \\
\text { subgenre }\end{array}$ & $\begin{array}{l}\text { Random } \\
\text { matching } \\
\text { medical } \\
\text { subgenre }\end{array}$ & $\begin{array}{l}\text { Spy/action } \\
\text { subgenre }\end{array}$ & $\begin{array}{l}\text { Random } \\
\text { matching } \\
\text { Spy/action } \\
\text { subgenre }\end{array}$ & $\begin{array}{l}\text { Criminal } \\
\text { forensic } \\
\text { investigation } \\
\text { subgenre }\end{array}$ & $\begin{array}{l}\text { Random } \\
\text { matching } \\
\text { criminal } \\
\text { forensic } \\
\text { investigation } \\
\text { subgenre }\end{array}$ \\
\hline 1,000 & 88.29 & 90.22 & 91.71 & 90.38 & 88.08 & 90.56 \\
\hline 2,000 & 92.65 & 94.42 & $95.63^{*}$ & 94.47 & 92.92 & 94.58 \\
\hline 3,000 & 94.85 & $96.21 *$ & 96.85 & $96.19 *$ & $95.01 *$ & $96.25^{*}$ \\
\hline 4,000 & $95.92 *$ & 97.27 & 97.74 & 97.27 & 96.21 & 97.28 \\
\hline 5,000 & 96.65 & 97.83 & 98.28 & 97.86 & 97.02 & 97.82 \\
\hline 6,000 & 97.1 & 98.29 & 98.63 & 98.31 & 97.49 & 98.24 \\
\hline 7,000 & 97.42 & 98.54 & 98.77 & 98.54 & 97.81 & 98.53 \\
\hline 8,000 & 97.72 & 98.74 & 98.92 & 98.74 & 98.11 & 98.74 \\
\hline 9,000 & 97.94 & 98.9 & 99.02 & 98.92 & 98.31 & 98.91 \\
\hline 10,000 & 98.14 & 99.05 & 99.14 & 99.09 & 98.47 & 99.05 \\
\hline 11,000 & 98.33 & 99.16 & 99.22 & 99.19 & 98.63 & 99.16 \\
\hline 12,000 & 98.45 & 99.25 & 99.29 & 99.27 & 98.9 & 99.24 \\
\hline 13,000 & 98.53 & 99.3 & 99.34 & 99.33 & 98.99 & 99.29 \\
\hline 14,000 & 98.63 & 99.33 & 99.36 & 99.36 & 99.08 & 99.35 \\
\hline Proper nouns & 1.94 & 2.53 & 3.59 & 2.48 & 2.75 & 2.77 \\
\hline $\begin{array}{l}\text { Marginal } \\
\text { words }\end{array}$ & 0.87 & 0.66 & 0.41 & 0.73 & 0.73 & 0.81 \\
\hline $\begin{array}{l}\text { Not in the } \\
\text { lists }\end{array}$ & 1.38 & 0.67 & 0.64 & 0.65 & 0.93 & 0.66 \\
\hline Tokens & 266,856 & 266,856 & 182,620 & 182,620 & 215,658 & 215,658 \\
\hline Types & 11,688 & 12,626 & 7,570 & 10,233 & 11,548 & 11,136 \\
\hline Families & 5,930 & 7,069 & 4,450 & 5,964 & 6,356 & 6,417 \\
\hline
\end{tabular}

Note. *reaching $95 \%$ coverage

Table 2. The cumulative coverage including proper nouns and marginal words of programs within the subgenres and the random matching episodes calculated using RANGE.

Table 2 also shows the cumulative coverage for the subgenres and the matching random programs. It is important to look at the cumulative coverage because it provides some indication of the vocabulary size necessary for comprehension as well as the vocabulary load; a higher proportion of high frequency words indicates a smaller lexical load. The table shows that the vocabulary size necessary to reach $95 \%$ coverage varied between the subgenres and the random programs. A vocabulary size of 4000 word families plus proper nouns and marginal words is necessary to reach $95.92 \%$ coverage of the medical programs. In contrast, a 
vocabulary size of 3000 word families plus proper nouns and marginal words reaches $96.21 \%$ coverage in the random corpus matched with the medical subgenre.

Viewers would need to know fewer words to reach $95 \%$ coverage of the spy/action subgenre than the random matching episodes. A vocabulary size of 2000 word families plus proper nouns and marginal words reaches $95.63 \%$ coverage for all of the episodes of 24 and Alias together. In contrast, a vocabulary size of 2000 word families plus proper nouns and marginal words reaches only $94.47 \%$ coverage in the random episodes matched with the spy subgenre. At the 3000 word level coverage was $96.85 \%$ for the spy subgenre. The criminal forensic investigation programs and the random episodes matched with it followed the same pattern as the medical programs; viewers would need to know more words to reach $95 \%$ coverage of the crime programs than the matched random episodes. A vocabulary size of 3000 word families plus proper nouns and marginal words provided $95.01 \%$ coverage. In comparison, a vocabulary size of 3000 word families plus proper nouns and marginal words reaches $96.25 \%$ coverage of the random episodes.

Table 3 shows the number and percentage of encounters with word families from the 4,000-14,000 word lists in the subgenres and the random episodes. In this comparison between subgenres and random episodes it is important to look at the percentages rather than the number of encounters because the number of low frequency tokens varies. For example, there are more low frequency tokens in the medical subgenre $(10,069)$ than in the random episodes matched with the medical subgenre $(8,323)$ because the cumulative coverage was higher at the 3,000 word level for the random episodes.

The results were consistent between the three subgenres and indicate that there is greater potential for incidental vocabulary learning through watching different episodes of programs from the same subgenre than watching random television programs. The percentage of words encountered once was lower in all three subgenres and the percentage of words encountered 10 or more times was higher in all three subgenres than in the matched random episodes. In the medical subgenre $46 \%$ of words were encountered once and $9 \%$ were encountered 10 or more times. In the random episodes matched with the medical subgenre $49 \%$ of the words were encountered once and $4 \%$ were encountered 10 or more times. In the spy/action subgenre 54\% of words were encountered once and 5\% were encountered 10 or more times. In the random episodes matched with the spy/action subgenre 55\% of the words were encountered once and $4 \%$ were encountered 10 or more times. In the criminal forensic investigation subgenre $49 \%$ of words were encountered once and 5\% were encountered 10 or 
more times. In the random episodes matched with the criminal forensic investigation subgenre $54 \%$ of the words were encountered once and $3 \%$ were encountered 10 or more times.

\begin{tabular}{|c|c|c|c|c|c|c|c|c|c|c|c|c|}
\hline \multirow{2}{*}{$\begin{array}{l}\text { Number of } \\
\text { encounters }\end{array}$} & \multicolumn{2}{|l|}{$\begin{array}{l}\text { Medical } \\
\text { subgenre }\end{array}$} & \multicolumn{2}{|l|}{$\begin{array}{l}\text { Random } \\
\text { matching } \\
\text { medical } \\
\text { subgenre }\end{array}$} & \multicolumn{2}{|c|}{$\begin{array}{l}\text { Spy/action } \\
\text { subgenre }\end{array}$} & \multicolumn{2}{|c|}{$\begin{array}{l}\text { Random } \\
\text { matching } \\
\text { Spy/Action } \\
\text { subgenre }\end{array}$} & \multicolumn{2}{|c|}{$\begin{array}{l}\text { Criminal } \\
\text { forensic } \\
\text { investigation } \\
\text { subgenre }\end{array}$} & \multicolumn{2}{|c|}{$\begin{array}{l}\text { Random } \\
\text { matching } \\
\text { criminal } \\
\text { forensic } \\
\text { investigation } \\
\text { subgenre }\end{array}$} \\
\hline & Amount & $\%$ & Amount & $\%$ & Amount & $\%$ & Amount & $\%$ & Amount & $\%$ & Amount & $\%$ \\
\hline 1 encounter & 1,159 & $46 \%$ & 1,408 & $49 \%$ & 774 & $54 \%$ & 1,256 & $55 \%$ & 1,285 & $49 \%$ & 1,340 & $54 \%$ \\
\hline 2 encounters & 469 & $19 \%$ & 568 & $20 \%$ & 258 & $18 \%$ & 457 & $20 \%$ & 479 & $18 \%$ & 480 & $19 \%$ \\
\hline $\begin{array}{l}3-4 \\
\text { encounters }\end{array}$ & 398 & $16 \%$ & 462 & $16 \%$ & 205 & $14 \%$ & 323 & $14 \%$ & 397 & $15 \%$ & 358 & $14 \%$ \\
\hline $\begin{array}{l}5-7 \\
\text { encounters } \\
8-9\end{array}$ & 197 & $8 \%$ & 238 & $8 \%$ & 89 & $6 \%$ & 132 & $6 \%$ & 245 & $9 \%$ & 187 & $7 \%$ \\
\hline $\begin{array}{l}\text { encounters } \\
10+\end{array}$ & 74 & $3 \%$ & 71 & $2 \%$ & 35 & $2 \%$ & 34 & $1 \%$ & 63 & $2 \%$ & 55 & $2 \%$ \\
\hline encounters & 227 & $9 \%$ & 128 & $4 \%$ & 78 & $5 \%$ & 82 & $4 \%$ & 139 & $5 \%$ & 79 & $3 \%$ \\
\hline $\begin{array}{l}\text { Mean } \\
\text { encounters } \\
\text { for } 10+\end{array}$ & 21 & & 18 & & 23 & & 18 & & 23 & & 20 & \\
\hline $\begin{array}{l}\text { Total word } \\
\text { families }\end{array}$ & 2,524 & & 2,875 & & 1,439 & & 2,284 & & 2,608 & & 2,499 & \\
\hline Total tokens & 10,069 & & 8,323 & & 4,580 & & 5,763 & & 8,754 & & 6,655 & \\
\hline
\end{tabular}

Table 3. Number and percentage of encounters with 4,000-14,000 level word families in the subgenres and the matching random episodes calculated using RANGE.

It is important to note that the number of words that were encountered 10 or more times in the episodes was less in the spy/action subgenre (78) than in the matching random episodes (82). This was probably due to the fact that there were $21 \%$ fewer low frequency tokens in the spy/action subgenre $(4,580)$ than in the matched random episodes $(5,763)$. The percentage of words encountered 10 or more times and the mean number of times those words were encountered in the spy programs indicates that even if there are fewer lower frequency words occurring in related programs, there is greater potential for learning those words than in random television programs.

\section{DISCUSSION}

The present study expanded upon recent corpus-driven research on television programs (Webb \& Rodgers, 2009a), narrow viewing (Rodgers \& Webb, in press), and narrow reading (Gardner, 2004; Hwang \& Nation, 1989; Schmitt \& Carter, 2000; Sutarsyah, Nation, \& 
Kennedy, 1994) by looking at the vocabulary in pairs of television programs with related content in comparison to sets of random television programs. The analysis should provide some indication of the extent to which vocabulary is likely to reoccur within related programs and unrelated programs. It should also indicate the potential for incidental vocabulary learning within those sets.

In answer to the first research question, the results indicated that television programs within the same subgenre are likely to have fewer word families than random television programs; however, the number of word types may vary between related and unrelated programs. Because research on the psychological reality of word families shows that knowing the stem of a word may facilitate recognition of its inflectional and derivational members (Bertram, Laine, \& Virkkala, 2000; Nagy, Anderson, Schommer, Scott, \& Stallman, 1989; Wysocki \& Jenkins, 1987), the results for word families should provide an accurate assessment of the vocabulary load for watching television. In all three subgenres, the number of word families was less than in the sets of matched random episodes. There were $16 \%$ fewer word families in the medical subgenre, $25 \%$ fewer word families in the spy/action subgenre, and $1 \%$ fewer word families in the criminal forensic investigation subgenre than in the sets of random matching episodes. There were also $7 \%$ fewer word types in the medical subgenre and $26 \%$ fewer word types in the spy/action subgenre, but $4 \%$ more word types in the criminal forensic investigation subgenre than in the random episodes matched with each subgenre. The relatively large number of types and families in the criminal forensic investigation subgenre indicates that there may have been less overlap in content and storylines between the two programs (CSI and Crossing Jordan), in comparison to the programs in the other two subgenres. This may also indicate that selecting programs with a high degree of overlap in content and storylines may be challenging.

The findings are supported by previous research on narrow viewing which has shown that different episodes of the same program had a lower vocabulary load than random television programs (Rodgers \& Webb, in press), and research on narrow reading which has shown that related texts have a lower vocabulary load than unrelated texts (Hwang \& Nation, 1989; Schmitt \& Carter, 2000; Sutarsyah, Nation, \& Kennedy, 1994). The results have pedagogical value because they indicate that related television programs are likely to have a lower vocabulary load than unrelated television programs, and may be easier for viewers to understand because a smaller range of vocabulary is likely to be found in television programs from within the same subgenre than in random television programs.

The results of this study as well as previous studies (Rodgers \& Webb, in press; Webb $\&$ Rodgers, 2009a) showed that the vocabulary size necessary to understand programs may vary between programs and genres. A vocabulary size of 2,000 word families was sufficient to reach $95 \%$ coverage of the spy/action subgenre, a vocabulary size of 3,000 word families was necessary to reach $95 \%$ coverage of the forensic criminal investigation subgenre and the 
random sets of programs, and a vocabulary size of 4,000 word families was necessary to reach 95\% coverage of the medical subgenre. This means that while related programs may have fewer word families, it is still particularly important to select programs and genres for language learning which consist of a greater percentage of high frequency words if comprehension is a challenge for viewers.

Programs from the medical subgenre and the criminal forensic investigation subgenre to a lesser extent may have a greater number of low frequency words because they contain more genre specific technical vocabulary. For example, in the medical subgenre the following are some of the technical words encountered 20 or more times: aneurysm, bacterium, biopsy, cardiac, diagnosis, hallucinate, lumbar, ovary, pulmonary, seizure, syndrome, toxin, tuberculosis, tumor, and vomit. There are two useful ways of dealing with these words. Prelearning the 10 most frequent word families that are likely to be unknown has the potential to improve comprehension by increasing vocabulary coverage (Webb, 2010b). Pre-teaching words before viewing English language videos has been found to increase comprehension (Chung, 2002). Creating glossaries of these words is also likely to aid comprehension through increased coverage (Webb, 2010c).

In answer to the second research question, the results indicated that word families are more likely to reoccur in programs from within the same subgenre than in random television programs. There was a higher percentage of low frequency (4,000-14,000 level) word families encountered 10 or more times in each of the sets of programs within the same subgenre than in the matched random episodes. The percentage of word families encountered 10 or more times ranged from $5 \%$ in both the spy/action and criminal forensic investigation subgenres to $9 \%$ in the medical subgenre. In contrast, the percentages ranged from $3 \%$ in the random episodes matched with the criminal forensic investigation subgenre to $4 \%$ for the other two sets of matched random episodes. There was also either a higher or equivalent percentage of low frequency word families encountered 8-9 times, 5-7 times, and 3-4 times in the programs within the same subgenres. In contrast, there was a higher percentage of word families encountered once and twice in the matched random episodes than within the programs from the same subgenre. For example, $46 \%$ of the words in the medical subgenre, $54 \%$ of the words in spy/action subgenre, and $49 \%$ of the words in the criminal forensic investigation subgenre were encountered only once, whereas, the percentages were $49 \%, 55 \%$, and $54 \%$, respectively in the matched random episodes. Taken together, the results indicate that watching television programs with related content may be a more effective way of learning vocabulary than watching random programs because unknown words are more likely to reoccur in programs with related content.

Research investigating incidental vocabulary learning through watching television indicates that both L1 viewers (Oetting, Rice, \& Swank, 1995; Rice \& Woodsmall, 1988) and L2 viewers (d'Ydewalle \& Pavakanun, 1995; d'Ydewalle \& Van de Poel, 1999; Koolstra \& Beentjes, 1999; Neuman \& Koskinen, 1992; Pavakanun \& d'Ydewalle, 1992) do incidentally 
learn words through watching television. Although there has not been any research examining the number of encounters necessary to learn words incidentally through extensive viewing, it is likely that learning words through watching television is similar to learning words through reading. Research on incidental vocabulary learning through reading has shown that the more words are encountered in context, the more likely they are to be learned (Horst, Cobb, \& Meara, 1998; Jenkins, Stein, \& Wysocki, 1984; Rott, 1999; Saragi, Nation, \& Meister, 1978; Waring \& Takaki, 2003; Webb, 2007). The number of encounters necessary to learn words is likely to be a function of the amount of information present in the context in which the words are encountered (Webb, 2008). With reading this may relate primarily to the semantic relationships between words in the text. However, with television it may also be a function of the clarity of the discourse, the speed of the discourse, and the amount of semantic overlap between the imagery and the vocabulary.

In answer to the third research question, the number of word families encountered 10 or more times within a full season of two programs from the same subgenre ranged from 78 in the spy/action subgenre to 227 in the medical subgenre for a total of 444 word families. The mean number of encounters for these items ranged from 21-23 indicating that these word families were encountered often within the subgenres. If we count the word families that were encountered 10 or more times as potentially learned items, then the results indicate that there is potential for significant incidental vocabulary through watching two seasons of television programs with related content. It is also useful to look at the number of word families encountered five or more times because five encounters with words in context may be sufficient to gain partial knowledge of these items. The number of word families encountered five or more times within a full season of two programs from the same subgenre ranged from 202 for the spy/action subgenre to 498 for the medical subgenre for a total of 1147 word families. It is also important to note that viewers are also likely to gain knowledge of higher frequency words through watching television programs. Tests of vocabulary size may indicate that these words are known. However, it is unlikely that learners have full knowledge of these words. Further encounters with high frequency items in original contexts are likely to strengthen different aspects of vocabulary knowledge for those words.

It is also useful to look at the potential for vocabulary learning through watching random television programs. The number of word families encountered 10 or more times within an amount of random television episodes that is equivalent to a full season of two programs ranged from 79 to 128 for a total of 289 word families. The mean number of encounters for these items ranged from 18-20 indicating that these word families were also encountered often within the random programs. The number of word families encountered five or more times in the matched random episodes ranged from 248 to 437 for a total of 1006 word families. Although the results for the sets of random episodes are not quite as high as they are for the subgenres, the data for the random episodes indicates that there is great potential for incidental vocabulary learning through regular viewing of television programs. 
Each of the sets consisted of approximately 34 hours of viewing time. If learners are able to understand and enjoy L2 television programs this figure may represent a relatively small amount of viewing time.

It is important to note, however, that the amount of low frequency vocabulary is a function of the coverage at the 3000 word level. For example, in the medical subgenre, the vocabulary coverage was relatively low at the 3000 word level $(94.85 \%)$. This means that there were a relatively large number of low frequency words found in these episodes. It also means that the degree of comprehension could be relatively low because viewers need to know more words to reach $95 \%$ coverage. Conversely, the random episodes matched with the medical subgenre had a much higher coverage at the 3,000 word level $(96.21 \%)$. The higher coverage indicates that these episodes may be easier to understand because viewers need fewer words to reach $95 \%$ coverage. Together the results show that there may be a trade-off between comprehension and vocabulary learning. If there is higher coverage at the 3,000 word level there may be better comprehension but there will be fewer encounters with low frequency items. On the other hand higher coverage may provide better conditions to learn words; there is likely to be greater understanding of the information in the contexts that can be used to learn unknown items (Liu \& Nation, 1985). Further research examining the effects of coverage on vocabulary learning would be a useful follow-up to this study.

\section{CONCLUSION}

The present study provides some direction on how television might be effectively used. Watching L2 television programs is likely to be difficult at first. Initially the speed of the dialogue, the unfamiliar spoken forms of words that have only been encountered previously in text and the amount of spoken input may be overwhelming. If comprehension is challenging, it may be more effective to watch television programs with related content and storylines than programs with unrelated content. Watching similar programs is likely to reduce the lexical burden and may also increase background knowledge which may aid comprehension when viewing subsequent episodes with similar content. The primary aim when teaching with L2 television programs should be to support comprehension because if viewers can understand L2 television programs they are more likely to watch them regularly. The findings in this study suggest that regular viewing of related programs may lead to large incidental vocabulary learning.

\section{NOTES}

${ }^{1}$ For more information about the word lists see Nation (2004, 2006). 


\section{REFERENCES}

Adolphs, S., \& Schmitt, N. (2003). Lexical coverage of spoken discourse. Applied Linguistics, 24, 425-438.

Bada, E. \& Okan, Z. (2000). Students' language learning preferences. TESL - EJ, 4(3), 1-15.

Bauer, L., \& Nation, P. (1993). Word families. International Journal of Lexicography, 6(4), 253-279.

Bertram, R., Laine, M., \& Virkkala, M. M. (2000). The role of derivational morphology in vocabulary acquisition: get by with a little help from my morpheme friends, Scandinavian Journal of Psychology, 4, 2-15.

Biber, D. (2009). A corpus-driven approach to formulaic language in English: Multi-word patterns in speech and writing. International Journal of Corpus Linguistics, 14(3), 275-311.

Chung, J-M. (2002). The effects of using two advance organizers with video texts for the teaching of listening in English. Foreign Language Annals, 35(2), 231-241.

Cobb, T. (2007). Computing the vocabulary demands of L2 reading. Language Learning and Technology, 11(3), 38-63.

d'Ydewalle, G., \& Pavakanun, U. (1995). Acquisition of a second/foreign language by viewing a television program. Psychology of media in Europe: The state of the art-perspectives for the future, 51-64.

d'Ydewalle, G., \& Van de Poel, M. (1999). Incidental foreign-language acquisition by children watching subtitled television programs. Journal of Psycholinguistic Research, 28(3), 227-244.

Gardner, D. (2004). Vocabulary input through extensive reading: A comparison of words found in children's narrative and expository reading materials. Applied Linguistics, 25(1), 1-37.

Gieve, S. \& Clark, R. (2005). 'The Chinese approach to learning': Cultural trait or situated response? The case of a self-directed learning programme. System, 33, 261-276.

Horst, M. (2009). Revisiting classrooms as lexical environments. In T. Fitzpatrick \& A. Barfield (Eds.), Lexical Processing in Second Language Learners (pp. 53-66). Bristol, UK: Multilingual Matters.

Horst, M., Cobb, T., \& Meara, P. (1998). Beyond A Clockwork Orange: Acquiring second language vocabulary through reading. Reading in a Foreign Language, 11(2), 207-223.

Hwang, K., \& Nation, P. (1989). Reducing the vocabulary load and encouraging vocabulary learning through reading newspapers. Reading in a Foreign Language, 6(1), 323-335.

Jenkins, J. R., Stein, M. L., \& Wysocki, K. (1984). Learning vocabulary through reading. American Educational Research Journal, 767-787.

Koolstra, C. M., \& Beentjes, J. W. J. (1999). Children's vocabulary acquisition in a foreign language through watching subtitled television programs at home Educational Technology Research and Development, 47(1), 51-60.

Laufer, B. (1989). What percentage of text lexis is essential for comprehension? In C. Lauren \& M. Nordman (Eds.), Special Language: From Humans Thinking To Thinking Machines, (pp. 316323). Clevedon: Multilingual Matters.

Liu, N. \& Nation, I.S.P. (1985). Factors affecting guessing vocabulary in context. RELC Journal, 16(1), 33-42.

Meara, P. M. (1991). BBC English Core Curriculum: the Lexicon. London: BBC English.

Meara, P. M. (1993). Tintin and the World Service: a look at lexical environments. IATEFL: Annual Conference Report. 32-37.

Meara, P. M., Lightbown, P. M., \& Halter, R. (1997). Classrooms as lexical environments. Language Teaching Research, 1(1), 28-47.

Nagy, W. E., Anderson, R., Schommer, M., Scott , J. A., \& Stallman, A. (1989). Morphological families in the internal lexicon. Reading Research Quarterly, 24(3), 263-282.

Nation, I. S. P. (2004). A study of the most frequent word families in the British National Corpus. In P. Bogaards \& B. Laufer (Eds.), Vocabulary in a second language: Selection, acquisition, and testing (pp. 3-13). Amsterdam: John Benjamins.

Nation, I. S. P. (2006). How large a vocabulary is needed for reading and listening? Canadian Modern Language Review, 63(1), 59-82.

Nation, I. S. P., \& Heatley, A. (2002). Range: A program for the analysis of vocabulary in texts [software]. Downloadable from http://www.victoria.ac.nz/lals/staff/paul-nation/nation.aspx

(C) Servicio de Publicaciones. Universidad de Murcia. All rights reserved. IJES, vol. 11 (1), 2011, pp. 117-135 
Nation, P., \& Wang, K. (1999). Graded readers and vocabulary. Reading in a Foreign Language, 12(2), 355-380.

Nation, I.S.P., \& Webb, S. (2011). Researching Vocabulary. Boston, MA: Heinle.

Neuman, S. B., \& Koskinen, P. (1992). Captioned television as comprehensible input: Effects of incidental word learning from context for language minority students. Reading Research Quarterly, 95-106.

Oetting, J. B., Rice, M. L., \& Swank, L. K. (1995). Quick incidental learning (QUIL) of words by school-age children with and without SLI. Journal of Speech, Language and Hearing Research, $38(2), 434-445$.

Pavakanun, U., \& d'Ydewalle, G. (1992). Watching foreign television programs and language learning. NATO ASI Series F Computer and Systems Sciences, 87, 193-193.

Rice, M. L., \& Woodsmall, L. (1988). Lessons from television: Children's word learning when viewing. Child Development, 420-429.

Rodgers, M. P.H., \& Webb, S. (in press). Narrow viewing: The vocabulary in related television programs. TESOL Quarterly.

Rott, S. (1999). The effect of exposure frequency on intermediate language learners' incidental vocabulary acquisition and retention through reading. Studies in Second Language Acquisition, 21(04), 589-619.

Saragi, T., Nation, I. S. P., \& Meister, G. F. (1978). Vocabulary learning and reading. System, 6(2), 72-78.

Schmitt, N., \& Carter, R. (2000). The lexical advantages of narrow reading for second language learners. TESOL Journal, Spring 2000, 4-9.

Sutarsyah, C., Nation, P., \& Kennedy, G. (1994). How useful is EAP vocabulary for ESP? A corpus based case study. RELC Journal, 25(2), 34-50.

Waring, R., \& Takaki, M. (2003). At what rate do learners learn and retain new vocabulary from reading a graded reader. Reading in a Foreign Language, 15(2), 130-163.

Webb, S. (2010a). A corpus driven study of the potential for vocabulary learning through watching movies. International Journal of Corpus Linguistics, 15(4), 497-519.

Webb, S. (2010b). Pre-learning low frequency vocabulary in second language television programs. Language Teaching Research, 14(4), 501-515.

Webb, S. (2010c). Using glossaries to increase the lexical coverage of television programs. Reading in a Foreign Language, 22, 201-221.

Webb, S. (2008). The effects of context on incidental vocabulary learning. Reading in a Foreign Language, 20, 232-245.

Webb, S. (2007). The effects of repetition on vocabulary knowledge. Applied Linguistics, 28, 46-65.

Webb, S. \& Rodgers, M.P.H. (2009a). The vocabulary demands of television programs. Language Learning, 59(2), 335-366.

Webb, S. \& Rodgers, M.P.H. (2009b). The lexical coverage of movies. Applied Linguistics, 30, 407427.

Wodinsky, M., \& Nation, I. S. P. (1988). Learning from graded readers. Reading in a Foreign Language, 5(1), 155-161.

Wysocki, K., \& Jenkins, J. R. (1987). Deriving word meanings through morphological generalization.

Reading Research Quarterly, 22(1), 66-81. 


\section{APPENDIX}

Random programs matched with medical dramas

\section{Program}

30 Rock

Beverly Hills 90210

Alf

Aliens in America

Ally McBeal

American Dad

Andromeda

Andy Barker P.I.

Back to You

Big Day

Carpoolers

Criminal Minds

Crusoe

Desperate Housewives

Dharma Greg

Eli Stone

Everybody Hates Chris

Everybody Loves Raymond

Flash Gordon

Friends

Heroes

In Justice

Kidnapped

Kyle XY

Lois \& Clark: The New Adventures of Superman

Lost

Men in Trees

Monk

My Name Is Earl

New Amsterdam

Numb3rs

Pepper Dennis

Private Practice

Privileged

Pushing Daisies

Scrubs

Seinfeld

Shark

Smallville

Star Trek The Next Generation

Stargate SG-1

Studio 60 on the Sunset Strip

The 4400

The Black Donnellys

The Dead Zone

The L Word

The Nanny

The New Adventures Of Old Christine

The O.C.

\section{Episode title}

Secrets and Lies

Love Me or Leave Me

Fever

Rocket Club

Boy Next Door

The Most Adequate Christmas Ever

The Honey Offering

The Big No Sleep

A Gentleman Always Leads

Alice Can't Dance

The Troubles

Limelight

Hour 9 - Name of the Game

You Can't Judge A Book By It's Cover

Daughter of the Bride of Finkelstein

The Humanitarian

Everybody Hates Cutting School

Boys' Therapy

Ebb and Flow

The One With The Birthing Video

Five Years Gone

Side Man

Burn Baby Burn

The Future's So Bright I Gotta Wear Shades

Chi of Steel

Jughead

Kiss and Don't Tell

Mr. Monk Gets a New Shrink

We've Got Spirit

Golden Boy

Structural Corruption

Heiress Bridenapped -- Film at Eleven

Crime and Punishment

All About Defining Yourself

Bad Habits

My Lips Are Sealed

The Andrea Doria

Wayne's World

Power

Power Play

Avenger 2.0

The Friday Night Slaughter

Suffer the Children

A Stone of the Heart

Grains of Sand

Light My Fire

Stop the Wedding I Want to Get Off

Self-Esteem Tempura

The Pot Stirrer 
The Secret Life of the American Teenager The Simpsons

The War at Home

The West Wing

Threshold

Traveler

Twin Peaks

Two and a Half Men

Ugly Betty

Veronica Mars

Women's Murder Club

Xena Warrior Princess
Caught

The Seemingly Never-Ending Story

The Empire Spanks Back

The Stormy Present

Blood of the Children

The Trader

Episode Four

Look At Me Mommy I'm Pretty

Sisters on the Verge of a Nervous

Breakdown

Poughkeepsie Tramps \& Thieves

FBI Guy

Lyre Lyre Hearts on Fire 